\title{
Theoretical Reflections on Research in Educational Policys. Epistemologies of Education Policy Approach
}

\author{
César Tello \\ Department of Education, University National of Tres de Febrero, Argentina. \\ Department of Research and Development, University National of Tres de Febrero, Argentina \\ Latin American Network of Studies Epistemological
}

\begin{abstract}
This paper intends to introduce a theoretical reflection on the epistemological perspectives used in education policy research and the way in which those perspectives greatly influence the definition of the object of the theoretical field using the analytical category of the Epistemology of Education Policy Approach as a basis for analysis, leaving aside the State focused classical definition of the object of study of education policy. The premises assumed on this paper are, on the one hand, considering that education policy as a theoretical field is defined through the perspective and epistemological positioning of the person who interprets/characterizes it and, on the other hand, that that definition from a specified epistemological positioning responds to an episteme of epoch in terms of Foucault.
\end{abstract}

Key words: education policy researchers, objects of study, Epistemologies of Education Policy

\section{INTRODUCTION}

This paper aims to describe some epistemological notes on the field of education policy in Latin America, taking the category of the Epistemologies of Education Policy Approach (Tello 2009, $2010,2012,2013$ ) as a starting point to think about and reflect upon knowledge production in this field.

Given the field's historical and epistemological process current stage, the Epistemologies of Education Policy Approach (EEPA) comes to warn about two issues that, though not unknown, must be considered, namely: a) research and knowledge production non-neutrality (Habermas 1981, 1984; Leblond 1975; Sousa Santos 2006, 2009; among others), particularly in this paper, in education policy, and b) the need to determine the researcher's position, i.e. the epistemological position from which the research process is carried out, and on the basis of which epistemological perspective they develop their analysis and achieve certain outcomes (Tello 2010, 2011, 2012). It is worth mentioning that these two issues (a \& b) converge as focal points of the category of education epistemologies, as it will be explained later on.

In this sense, this paper supports Boaventura de Sousa Santos' (2006) thought, when he reports that knowledge production from a positivist perspective is taken as independent from culture. We can search for some sort of relative objectivity, since there are some methodologies that allow us to do so, but, we can never, as education policy researchers, position ourselves in a neutral ground, as Atilio Borón (2006) poses, given Max Weber's "value neutrality" postulate, which assumed, just as positivism, the fallacy of a "value-free" science and a radical separation between cognizant subject and cognizable object. Thus, not laying down the epistemological position would leave the researcher very close to a positivist position (which considers the neutrality of sciences and of knowledge produced) or near epistemological unacknowledgment 
to carry out an investigation. On the assumption that the position from which one speaks "is clear," many times the researcher does not review or explicitly states the epistemological postulates in the research process.

The epistemologies of education policy have, in the researcher's perspective, two dimensions of study, which are inherent and consecutive. The first dimension is the theoretical category in itself, understood as a conceptual structure that gives rise to the second dimension: the analysis and development of policy education research in epistemological code. In this paper, some general features of the first dimension will be outlined; the second dimension refers to what has been called meta-analysis in education policy research (See Tello and Mainardes, 2012).

On the basis of the suggested theorization for the development of education policy research through the EEPA, the traditional way of conceiving the object of study of education policy, i.e. the State, begins to be questioned. This issue will be revisited later on.

\section{SOME CONSIDERATIONS ABOUT THE CURRENT STATE OF KNOWLEDGE PRODUCTION IN EDUCATION POLICY IN LATIN AMERICA}

In a recent study (Tello and Mainardes, 2012), 118 articles in the education policy field from indexed journals listed in the Network of Latin American Scientific Journals (Red de Revistas Científicas de América Latina, Redalyc) comprising authors from Argentina, Brazil, Mexico, Chile, Colombia and Venezuela were analyzed. There, it has been observed that one of the main difficulties in the analysis of research studies entails awareness of the fact that the conceptual development carried out by researchers, based on some researcher-referent ${ }^{1}$, becomes methodology for the analysis, but the epistemological and ontological bases with which the theoretical referentials were constructed are disregarded.

Another missing element detected during the survey was the absence of the epistemological positioning of the researcher and, in some cases, the inclusion of epistemological matrices that led to research studies with poor theoretical consistency in their analysis and outcomes. Thus, the concern about the absence of an explicit epistemological positioning in recent field studies arises, as it has been pointed out somewhere else (Cf. Tello, 2009; 2010). As Mainardes puts it (2009) "many researchers do not explicitly state the theoretical assumptions that support their analysis [...] we observe the use of a set of authors (often of different epistemological matrices) in order to support their analysis. This renders the bases for these types of research studies vague and inconsistent" (p. 7). In the context of the discussion on theoretical-methodological bases of education policy research, the "epistemological positioning" category (Cf. Tello, 2009 \& 2010) is constructed, constituting itself in the focus of this study; its main idea being that the development of a piece of research relies on a certain worldview and, thus, an epistemological perspective is inevitably adopted. In this line of argument, it should be understood that the authors that develop categories of analysis assume specific epistemological positionings ${ }^{2}$, and the researcher's epistemological position is inherently linked to the perspective or to the relations among perspectives constructed and assumed in an investigation.

Therefore, it is necessary to point out that the education policy researcher can adopt an eclectic epistemological position, but they need to explicitly state and combine theoretically the

\footnotetext{
1 Among the main referent-authors used by researchers, we find: Stephen Ball, Roger Dale, Rolland Paulston, Peter McLaren, Tomaz Tadeu Da Silva, Baudelot and Establet, Giroux, Apple, Pierre Bourdieu, Basil Bernstein.

2 For example: “Globally structured educational agenda” by Roger Dale; “Social cartography” by Rollan Paulston; “The policy cycle” by Sphen Ball, among others.
} 
concepts and/or relations between perspectives, with a little more effort and accuracy than those who assume just one epistemological perspective for the development of their research.

It must also be considered that on many occasions, when conducting these epistemological procedures, 'opposed' or 'quite distinct' epistemological matrices are linked. In this case, the researcher will be facing the construction of a 'new epistemological perspective,' not to be confused with epistemological eclecticism ${ }^{3}$ or epistemological pluralism, as some analysts pose.

\section{APPROACH TO THE EPISTEMOLOGIES OF EDUCATION POLICY}

The EEPA is one possible way of dealing with the analysis of the research field in education policy, as it has been mentioned elsewhere (Tello, 2012), whether as a facilitative approach for the education policy researcher or as a means to develop studies on what has been called the "field of epistemological studies on education policy" (Tello, 2011, 2012), studies that the researcher in this paper considers meta-analytic studies on education policy.

Thus, the first use as a facilitative approach relates to the exercise of epistemological vigilance (Bourdieu et al., 2008) on the very process of investigation, contributing to set and specify the epistemological positioning of the education policy researcher. The concern that triggered the development of the EEPA was the mixture encountered in different texts referred to as "research."

The EEPA is believed to be an approach that deploys an analytic plan for the researchers of the field. In this sense, it is argued that the Approach should not be assumed as a prescriptive instrument to "know" how to conduct research on education policy. On the contrary, it is a flexible plan that aims to promote, through its components, the reflexivity on the process of investigation of the education policy field.

The Epistemologies of Education Policy Approach, EEPA, is made up of three elements: the epistemological perspective, the epistemological position and the epistemethodological approach ${ }^{4}$. The "Epistemologies" category is used in plural here since there are a number of epistemological positionings and perspectives to develop and carry out education policy research, i.e., there are several epistemologies in education policy as a theoretical field. On the basis of this premise and in a relational way, it can be pointed that depending on the different epistemologies, there will be various objects of study selected for analysis.

It is worth mentioning that in recent scenarios, knowledge frameworks are losing clarity and new lines of thought are emerging. Traditional knowledge frameworks, once believed to be stable, are being questioned. A growing number of authors consider knowledge foundational approaches, whether positivist, interpretive or Marxist, as incomplete or problematic. For example, Torsten Húsen (1990) acknowledges that no single paradigm can answer all questions. In other words, a paradigm, by definition, excludes those questions that considers irrelevant. This situation is configuring an epistemological scenario characterized by an emerging heterogeneity (Paulston, 1995).

\footnotetext{
3 There is a difference between 'new perspective' and 'eclecticism' since when stating an eclectic perspective, the researcher should pick epistemological matrices related in some way, in this case, we speak of what we have called "coherent linkage" of epistemological perspectives (Tello, 2010). When no such epistemological coherent linkage exists, we speak of a 'new epistemological perspective' or some sort of incoherent and inconsistent mode which affects the construction of the perspective and, thus, the development of research.

4 For further development and depth on these concepts, refer to Tello (2009; 2010; 2011; 2012a; 2012b; 2012 c; 2013a; 2013b; 2013c)
} 
Khun states that paradigms are completely relative, given that they are restrained and, at the same time, restrain the cultural and academic context of research and, in a way, there is no "theory" above paradigms.

This poses a big challenge to education policy researchers: Which are the epistemological flexibilities that we have in order to develop theoretical frameworks that allow us to understand reality? How do we conceive epistemological Marxism, post-structuralism or pluralism to understand the realities of education policy?

However, this idea also brings the possibility of a positivist approach in research since, if no epistemological positioning from which knowledge in education policy is produced, is specified, it could be argued that the researcher holds a neutral position, and that is never true. Thus, the education policy researchers' challenge consists of locating themselves in "a place" in order to look at reality therefrom; we all do that from a certain place. Furthermore, in the production framework of scientific knowledge, it should be understood that every piece of research must enrich itself from other research perspectives that give visibility to different knowledge areas, other entries and angles to approach a specific object of study. Believing all these aspects could be handled by a single research study supposes a degree of epistemological arrogance on the part of the researcher, given that they will never be able to go into the object of study in any depth, but rather border their object of study from multiple perspectives. On the other hand, if they have an epistemological perspective of analysis and include others as possible viewpoints, they will go deep into the object of study, leaving clues for others to go into these topics from other perspectives.

In this article, just the first two elements of the EPPA are considered in order to present ideas, assuming that the Epistemological Perspective in education policy research means the worldview adopted by the researcher in order to carry out their inquiries; we refer to the General Theory in terms of Glaser and Strauss (1967). Examples of perspectives may include: Marxism, neo-Marxism, structuralism, post-structuralism, existentialism, humanism, positivism and pluralism.

On the other hand, the Epistemological Positioning emerges from the Epistemological Perspective itself, or should emerge in a consistent and sound research. The Epistemological Positioning, i.e. the Substantive Theory (Glaser and Strauss, 1967), as it is understood in this paper, relates particularly to the object of study, that is, to the theoretical strands typical of the field, considering that substantive theories are those which directly relate to the empirical and theoretical content of the research's data. This is the focal point and the ribs of the EEPA, since it is in this point that the researcher's worldview is at stake; worldview meaning "a set of presuppositions (assumptions) that we hold about the basic constitution of reality" (Sire, 2004, p. 17). That is, not only ways of reading the reality, but also ways of building it in terms of epistemological reflexivity. In this sense, the epistemological positioning becomes the researcher's political and ideological position that relies on their choice of epistemological perspective, with which research will be conducted. Among the positionings, we may find: new institutionalist, institutionalist, legal, political constructivist, complexity, eclectic, post-modern, post-modernist, hyper-globalist, skeptical, neoliberal, transformational approach, functionalist, critical, radical critical, critical-analytical, resistance theorists, critical-reproductivist, humanist, economicist, etc. 
Several studies reveal that there is no researcher's "empty head" 5 and various methodological terms have been used to name this issue, for instance: "researcher's assumptions" or "meaning anticipation" (Sirvent, 1999), among others. In short, the epistemological positionings and perspectives do not emerge from an "empty head," on the contrary, they have substance and support. The difficulty arises when the education policy researcher cannot name what is happening to them as epistemological perspective or positioning and tries to build research from pseudo-neutrality, it is in that same line that they assume the object of study of education policy as a fossilized object.

Thus, Espina Prieto (2007) holds that object observation cannot be separated from the observing device. This assumes an object and a subject who knows it from within. That is, from our EEPA proposal, the object is not understood as a neutral entity, isolated from its context, where the researcher is not involved, but rather assumes a mutual involvement as starting point, what in terms of Norbert Elías (1993) would be "involvement with and detachment from" the object of study, and it is at that moment that the object "is selected." The isolation, construction and design of an object of study of education policy are carried out from an epistemological positioning. In this way, the intellectualist assumption of modern epistemology which assumes the reality as reflected in a mirror is excluded (Rorty, 1989).

That is why the epistemological assumption of reflexivity supposes the interaction between the subject, who begins their research from an epistemological positioning and perspective, and the object to be investigated, where subjectivity is understood as a constituent and builder of reality and knowledge, involved in a rhizomatic fold.

The term epistemology, of Greek origin, is usually understood as a synonym for theory of knowledge, i.e. the theory of knowledge production. Thus, it refers to the methodical and systematic knowledge, i.e. scientific knowledge. In terms of Bunge (1981), epistemology studies scientific research and scientific knowledge. That is, the modes of production and diffusion of a certain type of knowledge.

Taking these issues into account, "the epistemologies of education policy" refer to the analysis of the scientific nature of education policy as a theoretical field. Thus, epistemology does not confront reality, empiricism, real life. Epistemology studies scientific processes. From this paper's perspective, the scientific processes are inseparable theory and reality, development of knowledge and social processes.

However, it is worth mentioning that, on certain occasions, scientific knowledge discredits and sets aside the doxa, folk wisdom or the so called common beliefs. The discredit of such knowledge does not constitute a pillar of this paper's definition of epistemology. That is, it is believed that all kinds of knowledge should have a space, a "voice," it is just that there are a number of different types of knowledge; and some people believe that systematic knowledge is more important than folk wisdom, and this is an erroneous way of understanding knowledge from this paper's viewpoint. Notwithstanding, and according to the researcher's arguments, education policy epistemologies study the research processes of the field, and have no intention to deny the different types of knowledge and ways of knowing.

5 The "empty head" category is understood here as the position of a researcher who considers themselves as tabula rasa at the moment of beginning the research process. 
For some other authors, epistemology is that part of science, the object of which (though not the only one) is to go over the history of the subject as regards the construction of scientific knowledge, i.e. the way in which that subject has objectified, specialized and granted a scientificity status to such construct; but, at the same time, the recognition that this type of knowledge has on the part of the scientific community. This epistemology is the one that studies the genesis of sciences and searches thoroughly into the way the human being has transformed or understood their environment through several methods in an effort to explain and understand phenomena.

Thuillier (quoted by Mardones 1991) assumed the latter conception when considering the epistemology idea as "a science or philosophy of science that does not impose dogmas to scientists but studies the genesis and structure of scientific knowledge." Epistemology, for this author, is not a dogmatic system made up of unchanging and imposed laws, but rather a backward and forward movement through scientific knowledge that moves in the epoch imaginary, the reflections on it and the breakdown or "crisis" of the rules that support a particular paradigm typical of a scientific community (see Kuhn 2001).

What is meant by this is that "education policy epistemologies" do not confront empirical reality, whether material or symbolic, since empirical reality is the object of study of an education policy researcher. Epistemology that confronts empirical reality is nothing but a mere indolent abstraction. In this sense, in a conference given by Pedro Flores-Crespo in Buenos Aires, the researcher held that "it will be necessary to question the traditional epistemologies that have recently guided the analysis of policies. This inquiry cannot be separated from empirical evidence" (Conference, 2012).

The distinction between these categories becomes necessary to understand the EEPA, given that the approach may be understood as an epistemologisism or a hyperbolic exacerbation of the epistemological construct.

Thus, we make Nietzsche's words ours in our epistemological conception:

"Remain faithful to the earth, my brothers, with the power of your virtue. Let your giftgiving love and your knowledge serve the meaning of the earth. Thus I beg and beseech you. Do not let them fly away from earthly things and beat with their wings against eternal walls. Alas, there has always been so much virtue that has flown away. Lead back to the earth the virtue that flew away, as I do-back to the body, back to life, that it may give the earth a meaning, a human meaning" (Nietzsche).

Considering that an epistemology is always an "antropoethus" in terms of Edgar Morín (2001), the EEPA is assumed here as Sharon Gewirtz and Alan Cribb's challenge, which consists of conducting an "ethical reflexivity on the research work" $(2006$, p. 7$)$ in order to give reality a meaning, give the earth a meaning, a human meaning (Nietzsche).

\section{Education Policy as a Theoretical Field and the Epistemologies of Education Policy}

The field of education policy is defined here as a theoretical field equivalent to the academic field in terms of Bourdieu, insofar as from that field, knowledge (research) is produced, knowledge circulation (academic training) is triggered and use or application of such knowledge is developed (profession as political decision making), considering that these three spaces are not necessarily consecutive. As it was already stated, education policies constitute the object of study of education policy, in terms of its very own socio-educational reality in its 
multiple dimensions. Undoubtedly, this definition may be ascribable to the sociology of education, pedagogy, history of education, among others. However, it should be considered that various epistemic approaches generate an object in constant construction (Galindo Cáceres 1999). That is, the angles of analysis of the socio-educational reality allow for the theoretical field of education policy to be constructed from several axes that will merge into its object, for instance, the State, jurisprudence, micro-politics, political discourse, political debates, educational governance, right to education, among others.

The incipient characterization of the epistemologies of education policy may come to the aid of the epistemological status of the field; by this, the researcher here is not referring to a theoretical nucleus of "education policy" and it is not this paper's intent to set and define its nature as a discipline or science ${ }^{6}$, but rather its relation to several theoretical nuclei and methodological approaches, i.e. to the epistemologies of education policy. Therefore, the political and educational aspects constitute the focal points of the field, in the broad sense of the terms.

One of the main contributions this paper is believed to afford relates to its contribution to the epistemological strengthening of the theoretical field, without being its aim to distinguish between science, discipline or sub-discipline. On the contrary, the epistemological strengthening of the theoretical field takes place insofar as it assumes its multidisciplinarity and interdisciplinar complexity in the development of education policy research, which becomes evident in the multidimensionality of its epistemological positionings, epistemological perspectives and epistemethodological approaches. It is this multidimensionality that constitutes the epistemologies of education policy.

Basically being a field of the social sciences, it deploys from its own theoretical multiplicity, which does not question -from our perspective- its epistemological strength but rather places it as a solid and fertile space, given its diversity, to analyze education policies.

We can think of the possibility of defining some features of the epistemologies of education policy, but never consider that the "theory of education policy" could be defined, the latter meaning an epistemological reduction, since the current epistemological arguments do not demand "demarcation" between disciplines, that rather responds to classical studies and conceptions in the epistemological field that, for instance, distinguished between: sciencepseudoscience-disciplines, entering in the fake path of scientism; on the contrary, in this paper, the researcher assumes, in Wallerstein's (1997) sense, a position in favor of science and knowledge and against scientism.

In some European countries, some arguments and debates related to the assignment of a scientific status to the education policy field are taking place; such is the case of Spanish Jiménez Eguizábal et al. who wonder: "Are we facing the construction of a science of synthesis called the Science of Education Policy?" (2006, p. 263). Other debates focus on pedagogy in general -though these debates began decades ago-, as José Manuel Touriñan López (2008, p. 177) stance, that holds that each scientific discipline should have functional autonomy. In his words:

"functional autonomy means the possibility of conceiving a field of knowledge that should develop itself, not as a result of

${ }^{6}$ Demarcational positions are not supported given that, from this perspective, a distinction between discipline and science should be established. 
external pressures and recommendations coming from other fields equipped with a strong theoretical structure, but rather as a result of internal regulations deriving from the very field of knowledge, so that the theory of that field be restrained by the concepts, hypothesis and methodologies of the field and not by the theories pertaining to other fields."

Then, education policy field internal regulations are structured in some way on the basis of their relation to other fields of study, and that is where the epistemologies of education policy (using a term that appears to be contradictory) in its original state are to be found, and it is said "that appears to be contradictory" because its "original state" as a field relates to its connection to complex fields. In this way, the field of education policy is considered as a reticular space, insofar as a field of knowledge is defined from a contemporary epistemology as the possibility of new conceptual constructions that allow for numerous and reciprocal interactions between different fields of knowledge. In terms of Gianella (2006, p. 79): "The reticle has a doubly complex structure, given that in the lattice, elements that are in themselves lattices are admitted." In this way, we could adopt Deleuze rhizome perspective to think about the field of education policy, insofar as the fluency of any part of the rhizome can join another part.

However, returning to basic levels of research on social sciences -sometimes disregarded-, it is necessary to state once again a vital principle: research is not neutral, there is no such thing as an "untraceable position," on the contrary, the researcher produces knowledge from an epistemological position, particularly in education policy.

Epistemology, in its current conception, is understood as the Theory of Science. From this paper's perspective, the various approaches do not constitute "a theory" of the field, but rather it is the theories of education policy that form the theory, i.e. the epistemologies of education policy inherently understood, not as a science, but as an approach, method and systematic reflection; an epistemology that supports social, political and cultural connotations of knowledge and research.

We must consider Ball's argument (2006) when he refers to research on education policies and distinguishes between the structure of a piece of research, what he calls the "surface epistemology,"- i.e. the relationships between conceptualizations, research design and conduct- that constitute one way of doing epistemology, and what he calls "in-depth epistemology," -i.e. the explanation methods: realism, essentialism, critical perspective, among others- which should be considered for the soundness and consistency of such epistemology.

Taking these considerations into account, it can be pointed that there may be a Level I and a Level II epistemology, like the steps in a piece of research. As each level is advanced, these inherent steps offer feedback, for example, research design is not just a mere technical task nor is it devoid of epistemological positioning; and, as it was stated earlier, research is supported from its very beginning (the design, the objectives, the object construction, among others) from a given worldview. It would be naive to believe that any of these levels, mainly Level I, are devoid of epistemological positioning. According to Ball's postulates (2006), the problem is that a lot of research is conducted from what we call Level I, i.e. lots of research on education policy is research that develops and specifies just a "surface epistemology," however, these research studies do develop Level II to some extent given that they inevitably adopt an epistemological positioning. 
In terms of Bourdieu (2000), knowing the position "from which one speaks," which is the researcher's position, inviting to reflect on education policy epistemologies would consist of stating explicitly the epistemological positionings and approaches, as well as the epistemethodological approaches of education policy research so as to cross and go beyond the first epistemological level.

It should be considered that the presence per se of a theoretical framework and a methodological approach in a piece of research does not express the epistemology of education policy research, in that case, it would be a Level I epistemological analysis. It could be countered that those may be present as underlying elements, but, in that case, we will be facing an epistemological difficulty in terms of Bourdieu, given that what is not explicit refers to what is not conscious, as the author states, and in the "sociologist trade," it is very difficult to reflect on what is unconscious, because the researcher deploys their position in a 'naturalized' way: just for themselves.

Level II would account for the presence of an education policy epistemology. What is meant by this is that the theoretical framework of a piece of research is a supply for the analysis or epistemology of education policy, however, exercising the epistemologies of education policy is, in terms of Gewirtz (2007, p. 7), to conduct an "ethical reflexivity on the research work," reflect on the possible ethical consequences of research, in which way that work recognizes certain positionings as lawful and not others. In short, the ethical reflexivity is the way in which the researcher assumes the reality, in terms of Sousa Santos:

\begin{abstract}
"This is very important since with our positivist epistemology, we learn that science is independent from culture; however, the cultural assumptions of science are quite clear. Therefore, we are going to discuss how can we be objective, but not neutral and how can we distinguish between objectivity and neutrality as regards science. Objectivity, because we have common methodologies in social sciences in order to have knowledge; we hope the latter to be strict and defend us from dogmatisms; and, at the same time, we live in very unfair societies towards which we cannot remain neutral. We must be capable of doing this distinction, which is very important" $(2006, p .18)$.
\end{abstract}

As Galindo Cáceres (1998) points out, for many [researchers], this issue, i.e. the epistemological dimension, is irrelevant, as if it were beyond the scope of the researcher's trade. McLuhan states: "We don't know who discovered water, but we know it wasn't the fish." Actually, the people immersed in a process naturalize their own positionings without noticing the need to make them explicit. And here is where it is necessary to go back to Gewirtz's category, given that he believes that knowledge production "ethical reflexivity" in education policy impacts on the social world the researcher analyzes, and there lies the ethical responsibility of research as regards the requirement to state explicitly and clearly the researcher's epistemological position.

Education policy researchers often take the epistemologies of their research for granted, i.e. the elements of Epistemological Positioning, Epistemological Perspective and Epistemethodological Approach from which they conduct their research. These elements make up what has been called the Epistemologies of Education Policy Approach (EEPA) (Tello 2012). 


\title{
CHARACTERIZING THE OBJECT OF STUDY OF EDUCATION POLICY
}

In order to define the object of study of education policy, the epistemological positioning and perspective categories must be adopted in opposition to the demarcational epistemological arguments, thus, the definition of episteme of epoch in terms of Foucault is assumed, mainly as regards education policy as a teaching and content transmission space. In this sense, Castro (2006) explains:

\begin{abstract}
"It is not Foucault's intent to present the way in which the history of a given discipline turns out to be intelligible from the meaning tradition that inspired it from its founding acts, on the contrary, he aims to show that its emergence conditions respond to historical conditions of possibility that, on the one hand, are common to all or several bodies of knowledge of an epoch, and on the other hand, change from one epoch to another. Under the episteme notion, knowledge is not analyzed from its rational form perspective or objectivity, but from the point of view of the discontinuous homogeneity that governs the formation of different discourses that belong to the same epoch" $(2006, p$. 4).
\end{abstract}

It is in this line of analysis that the object of study of education policy is defined by its episteme of epoch, understanding that the object of study of education policy is just a contextual and historical construct.

The episteme of epoch may be observed in the various lines adopted by different countries when studying education policies, e.g.: Great Britain's political sociology, USA's politics and policies, the most traditional French strands in Education Management and Politics studies, or the latest conceptual developments in the sociopsycoanalytical perspective on education policy research or what on the French strand has been called the sociology of public action or cognitive analysis, that, in a way, begins to supersede traditional studies focused on the State. Pluralistic perspective analyses can also be seen in other studies (Tello and Mainardes, 2012) like Cochran (1993); Muller (1990, 2000); Muller and Surel (2002); Bronfenbrenner (1973, 1979 y 1993); Rossetti-Ferreira, Ramon and Silva (2002) productions.

Thus, the impact of these strands on the field should be considered. In a brief historicization, as a historical outline of the field of study of education policy, it could be stated that the foundational milestone of political science registers in 1948: at the request of UNESCO, experts and scholars meet in Paris in order to attempt the redefinition and delimitation of its object of study. After deliberations, the famous "List of subjects and fields of investigation" 7 was produced under a strong influence of Anglo-Saxon thought. Although the list is just a pragmatic enumeration of subjects, sixty years after its creation, it continues to be a benchmark for the formulation of theoretical frameworks and university curricula in relation to political science, including the curricular area in current education policy in pedagogy and education degree courses in Latin America.

It is from this date onwards, that political science as an object of study with "scientific aspiration" begins to be developed in several Latin American universities, and almost exclusively, from a legal-institutionalist approach (Barrientos del Monte, 2009).

As a result of the end of Second World War, welfare policies focused on issues like health and education were developed. Thus, the incipient emergence of a new way of conceiving public policies is observed in Latin America. Considering the deployment of welfare policies,

7 Subjects proposed are grouped in four categories: I. Political theory: a) Political theory. b) History of political ideas. II. Political institutions: a) The constitution. b) National Government. c) Regional and local government. d) Public administration. e) Economic and social functions of government. f) Comparative political institutions. III. Parties, groups and public opinion: a) Political parties. b) Groups and association. c) Participation of the citizen in the government and the administration. d) Public opinion. IV. International relations: a) International politics. b) International organization and administration. (UNESCO 1948). 
governmental organizations turned to social science researchers looking for solutions to issues posed by state activities, including those related to the growth and reform of the education system, i.e., as it was stated earlier, Laswell's pragmatic perspective.

In this framework, the more political science began to develop as a field of study, the more volume and variety of subjects to study; this became a problem at the moment -which is very common in emerging fields of knowledge- since it entailed a great effort in order to set a coherent logic in a growing number of subject matters that the field should study, but that opening effort (Bourdieu, 2000) would in some way give rise to education policy as an incipient space emerging -from the historical-epistemological perspective of the time- as a sub-discipline of political science.

Endowed with the main characteristics of political sciences, education policy emerged as a theoretical field in the fifties, with a strong approach focused on law making and comparative education, in some cases. The latter lacked the current epistemological development, and basically consisted of establishing legislative comparative axes between different countries and the structure of the education system, among other subjects of linear comparison, virtually decontextualized; though it undoubtedly responded to the analytical matrix of political sciences in Latin America, with a legal-institutionalist approach.

It is in this decade (1950) that in Argentina, Brazil, Chile, Mexico and Colombia, among other Latin American countries, some "institutionalization" of education policy as a field begins to be noticed through the creation of departments of education policies. It is worth mentioning that the researcher is not referring here to the beginning of political reflections on education, given that those could be tracked back to Aristotle or Plato, but rather to the "institutionalization" process in terms of Gómez Campo and Tenti Fanfani (1989), when they explain that when some practices are detached as specific practices, by way of the creation of a subject, a degree course, a private school or a department in the university sphere, it shows a historical process and the real presence of an institutional space that allows the circulation and production of knowledge.

As it was already stated, education policies constitute the object of study of education policy, in terms of its very own socio-educational reality in its multiple dimensions; it should be considered that various epistemic approaches generate an object in constant construction (Galindo Cáceres, 1999) That is, the angles of analysis of the socio-educational reality allow for the theoretical field of education policy to be constructed from several axes that will merge into its object, for instance, the State, jurisprudence, micro-politics, political discourse, political debates, educational governance, right to education, among others. Burch (2009), opposing to the classic definition of the object of study of education policy as a State action, explains that supporting the traditional model of the object of study of education policy is getting more and more difficult since the field is becoming increasingly congested: new relationships and forms of relationships are being established in and in relation to policy. Besides, he states that "the boundaries between state, economy and civil society are being blurred" since there is a multiplicity of voices within policy conversations and new conduits through which policy discourses enter policy thinking. As Ball puts it (2011, p. 11) "Education and social policy within government, are now thought, influenced and done in many different sites and the education policy community is increasingly diverse and unstable" which involves a shift in the development of "relations involving mutuality and interdependence as opposed to hierarchy and independence" (Peterson, 2003, p. 1. quoted in Ball, 2011). What is meant by this is that although there are methods of analysis of education policies focused on the State, those 
methods and analysis approaches cannot be the "classic" ones, given the new state configuration; it will be necessary to think of new plans of analysis applicable to the Statefocused analysis. Nevertheless, as explained below, the State cannot be the center of education policy in terms of research, but just an element of mediation. Remember this statement is made in analytical terms for research purposes, i.e., State should be relativized in terms of research on education policy; meaning if education policy research focuses on State, the remaining elements of political mediations that will not be investigated shall be assumed, and vice versa, if education policy research does not focus on State, it shall be assumed as just one element of the framework.

Bearing in mind this consideration, the common characterization of the object of study of education policy as a State action in relation to the education field can be questioned in some way. And therefore, in this paper, the researcher asks: What happens when the "state action" category is too vague? What happens when:

- the object of study of education policy constitutes itself as the way in which classes' interests are to be understood in connection with capital (neo-Marxist epistemological perspective)? or

- the state becomes a supranational state (hyper-globalist epistemological positioning)? or

- an analysis of power circulation at school is attempted (critical post-structuralist epistemological positioning)?

Whitty and Edwards (1994, p. 15) put forward the necessity of giving a definition of education policy assuming Jennings' argument (1977) in some way by summarizing politics as the product of a decision. For this purpose, the authors' state:

"But to reduce education policy to the sum of innumerable individual decisions, even decisions seen as partly predetermined or considerably constrained, is to ignore what in some analytical traditions would be called the power relations between different parts of the system and in others how decision-makers are positioned by different discourses."

However, it is clear that the authors try to give an operative definition in terms of organization of the field, since it is necessary to "reduce" [...] the sum of countless individual or collective decisions. The researcher's question here is why do the authors want to reduce?

The object of study of the education policy field is decision making. It is there that decisions may be observed at different levels of the education system as policy cycles in terms of Ball (1994) or complex decisions in terms of coalitions (Sabatier, 1988).

Thus, the researcher does not attempt to reduce the theoretical characterization of the object of study of education policy and assumes, as a conceptual approach dealing with the study of political decisions in the educational field, that there are political decisions at different levels of the education system and that those individual or joint decisions refer to the use of power. Therefore, it is necessary to distinguish the angles of study of this complex and rhizomatic object of study, for instance: curricular policies, teaching policies, funding policies, etc., that can be observed through the exercise of power of the government, the labor unionists, the teachers, the technicians, etc. at the micro, meso and macro-level of the education system or in their interrelation. 
It should be considered that modern State's rational approach assumed political exercise and decision as a "top down" line. However, some decision making goes far beyond government decisions; i.e. there are decisions beyond those made by the state government.

Here is the dilemma: the object of study of education policy should be defined for field organization purposes, or it could be pointed that its definition is not possible, unless it has an operative and strategic goal, as Whitty and Edwards have stated, setting the object of study of education policy as the decisions made solely by state governments. In this paper, the researcher's position is diametrically opposed to that definition.

Roth Deubel (2008) thus explains that there is certain centrality in the study of education policies, from a specific epistemological positioning as the Public Choice, that according to the author "focuses on the analysis of institutional agreements, mainly the design of state institutions and legal and constitutional rules" (Deubel, 2008, p. 80). In this sense, the Advocacy Coalitions position is adopted in this paper, structure created by Paul Sabatier, that began the search of a summary of the best devices provided by top down and bottom up approaches in the implementation study, incorporating actors' roles in a better way.

Flores Crespo and Mendoza (2012) explain that though it is possible that Sabatier's theoretical referential should not be widely known in Latin America due to the authoritarian and linear state actions in the region, it constitutes a powerful analytical plan for the study of education policies where multiples actors in several levels of decision making exist; and, at this point, it is necessary to go back to the category of episteme of epoch to ask ourselves: wouldn't be our own style of state government in the Latin American region that leads researchers to focus on it?

Bowe et al. (1992) warn about the difficulty of understanding and analyzing education policy in a vertical way; similarly, Raab (1994) explains that the State should be understood as one more element in the complex structure of education policies. In this sense, reflecting on Sabatier's theoretical referential, Deubel states that: "the unit of analysis cannot be limited to government structure but to a <political sub-system>. This sub-system, as part of the political system, is made up of a wide variety of public and private actors, actively involved or interested in a political problem or a controversy" (Deubel, 2008, p. 82).

Thus, the complex mobility of public policies is defined here in terms of swarming. This category, which lacks a clear Spanish translation, refers to bees moving in search of a place to build the honeycomb. The bees move together, and it is virtually impossible to identify their traditional hierarchy, since the search of the honeycomb building place is not restricted to the queen's decision.

In this sense, education policies as political action have multiple actors, connections, decisions, power struggles, actions, impact, implementation, etc. Considering the swarming image, the key question here is: can education policies be defined and conceptualized? Our argument is that an answer to that question will demand the writing of several encyclopedias that will never come to an end. However, in order to build an object of study, clearly artificial and from an epistemological positioning, an epistemethodological ${ }^{8}$ reduction may be carried out; i.e.

8 In Tello (2012), the epistemethodological category has been defined as the methodological moment at which the researcher chooses a methodology. 'Methodological approaches' are not considered as mere instruments, whether of data collection or analysis, but rather as a "logos method," i.e., the way of thinking the logos. Then, the researcher prefers the term epistemethodology, category in which method introduction and researcher's epistemological position merge. Although the methodological 
building an object of study to research on education policies involves acknowledging the swarming reduction and, at the same time, not being unaware -at least- of the main features of swarming and of the fact that that object will not be moving any more. It should also be noted that the analytical models for education policies analysis should not be determining factors. For instance, the attempt of answering these questions: where do education policies begin? or where do they end? is, undoubtedly, a way of assuming an epistemological positioning and perspective. From a top down or bottom up point of view, for example, this entails acknowledging the beginning and end in a pseudo-positivist vertical analysis. And if education policies could be thought of as a horizontal movement in a decisions continuum, which change step by step, gradually, from the authorities of a state government to a teacher, where decision making shows changes and more changes in the disorganized development of political action, where some include and change the others?

Thus, having made this characterization, it can be pointed that an education policy researcher who aims to characterize the theoretical field and its object of study will observe the theoretical field (swarming) from an epistemological positioning and an epistemological perspective, and never with an "empty head."

Some people consider education policies as a swarm, a honeycomb, located at some place, motionless, fossilized (though the bees are working inside). On the contrary, education policies are never still. For instance, a legislative decision involves decision making, perspectives, analyses, debates among every education system actor in a spiraled development that continues as a subjective construct, an intertextual trajectory. Stephen Ball has defined education policies as text and discourse; when referring to education policies as text, the author (Ball, 1994) explains that they are the product of a sinuous and unexpected trajectory, generated in the context of different political arenas, through struggles, commitments, interpretations and recreations of public authority, that will later be decoded by the actors who, in turn, will add different meaning, making minor context adjustments in a complex way. However, in this characterization, a vertical point of view with stages is kept regarding political trajectory (policy cycles) with main and supporting actors. In the education policy proposal as intertextuality, as swarming, texts are in constant change in political action. It is at this point that confusion arises with respect to the political trajectory, i.e. between those that have greater or lesser power in government actions. What is meant by this is that power struggles are carried on, but not necessarily, won by those with greater power. The process is much more complex, given that the mutual implications between the actors with different power levels change the other actor's power in an intertextual and rhizomatic perspective. Deleuze \& Guattari (1972:13) defined the rhizome as a descriptive model in which the organization of the elements do not follow hierarchical subordination lines -with a base or root from which a number of branches develop, according to the famous tree model of Porfirio-, on the contrary, in this model, any element can affect and influence any other element. In a traditional tree or hierarchical model, like policy cycles taxonomies, what is asserted about the higher level

\footnotetext{
approach has an epistemology, for common use distinction purposes, the latter term: epistemethodology is preferred. That is, it must be considered that methodology becomes epistemethodology insofar as this is related to the other elements: epistemological perspective and epistemological position. By itself and, for instance, for teaching purposes, it refers to methodologies alone; with greater conceptual precision, methodology could be understood in terms of methodological techniques, techniques that are many times taught as epistemologies in some cases, and without epistemological support in some other cases. Bourdieu (2000, p. 62) is sharply sarcastic regarding this prevalence stating that it is taken as a "series of recipes or rules that ought to be respected in order not to know the object but to be acknowledged as an expert on the object." Considering this warning, it is necessary that methodology in terms of research turn into epistemethodology, insofar as it constitute a consistent element of the three elements framework that make up the EEPA.
} 
elements is necessarily true about the subordinated elements, but not the other way around. In a rhizomatic model, any statement asserted about an element may influence the conception of the rest of the elements in the structure, regardless of its mutual position. Thus, the rhizome has no center.

In short, this paper aims to put forward the idea that education policies, in terms of political actions, make up a swarming-like rhizomatic intertextuality.

\section{CONCLUSION}

We are undoubtedly facing the emergence of a new way of understanding reality, the effects of which are changing radically our way of knowing the world and our way of relating to it as well. In this sense, it is believed that the epistemological debate in this theoretical field is yet quite limited. One of the main contributions this paper is believed to afford relates to its contribution to the epistemological strengthening of the theoretical field, without being its aim to distinguish between science, discipline or sub-discipline. On the contrary, the epistemological strengthening of the theoretical field takes place insofar as it assumes its multidisciplinarity and interdisciplinar complexity in the development of education policy research, which becomes evident in the wide variety of positionings and perspectives.

From the Latin American Network of Epistemological Studies on Education Policy (Red Latinoamericana de Estudios Epistemológicos en Política educativa, ReLePe) ${ }^{9}$, theoretical field studies are fostered, considering that concepts and categories used to analyze reality are not value-free. On the contrary, the selection of certain knowledge structures, paradigms and/or epistemological perspectives implies a positioning on the part of the researcher.

Thus, the consequences of the ideological crisis that impacted on the theoretical practices during the transition of the previous historical period to the current one, with the disqualification of the so called mega-narratives and the widespread deployment of the paradigm crisis idea should not be forgotten. As a result, general analytical models were abandoned and post-modernism was embraced, with the consequences showed by Perry Anderson: structures without history, history without subjects, theories without truth, a real suicide of theory and of any attempt of rational explanation of the world and its social relationships.

\section{References:}

Ball, S. J. (1994). Education reform: A critical and post-structural approach. Buckingham: Open University Press.

Ball, S. J. (2011). "Política social y educativa, empresa social, hibridación y nuevas comunidades discursivas." Propuesta Educativa Vol. 2, No. 36, pp. 25-34

Barrientos Del Monte, F. (2009). "La ciencia política en América Latina. Apuntes para una historia (estructural e intelectual) de la disciplina en la región." Seminario de Investigación del Área de Ciencia Política y de la Administración de la Universidad de Salamanca. Instituto Italiano di Scienze Umane, Florence, Italy.

Bourdieu, P. (2000). Los usos sociales de la ciencia. Buenos Aires: Nueva Visión.

Bowe, R. et al. (1992). Reforming education and changing schools: case studies in Policy Sociology. London: Routledge.

Bronfenbrenner, U. (1977). “Toward an experimental ecology of human development.” American Psychologist, Vol.

\footnotetext{
${ }^{9}$ www.relepe.org
} 


\section{2, No. 7, pp. 513-531.}

Bronfenbrenner, U. (1979). The Ecology of human development. Cambridge: Harvard University Press.

Bronfenbrenner, U. (1993). "The Ecology of cognitive development: research models and fugitive findings." In: R. H., Worzniak, and K. Fisher (Eds.). Scientific environments, New Jersey: Lawrence Erlbaum, pp. 3-44.

Burch, P. (2009). Hidden Markets: The new education privatization, Abingdon, Routledge,

Castro, E. (2006). "Michel Foucault: sujeto e historia." Tópicos. No. 14 pp. 171-183. Available online at: http://www.scielo.org.ar/scielo.php?script=sci_arttext\&pid=S1666-485X2006000100008\&lng=es\&nrm=iso Accessed in: 26 Abr. 2012.

Cochran, M. (1993). The International handbook of child care policies and programs. Westport; London: Greenwood Press.

Cox, C. (2006). "Construcción política de reformas curriculares: el caso de chile en los noventa." Profesorado. Revista de currículum y formación del profesorado, Spain, Vol. 10, No. 1, pp. 1-24.

Deleuze, G. and Guattari, F. (1972). L'Anti-Oedipe: Capitalisme et Schizophrenie. Editions de Minuit. Paperback

Deubel, A. N. (2008). “Perspectivas teóricas para el análisis de las políticas públicas: ¿de la razón científica al arte retórico?” Estudios Políticos, No. 33, pp. 67-91.

Dror, Y. (1983) Public Policy Making Reexamined. New Brunswick: NJ.

Elías, N. (1993) Compromiso y distanciamiento. Buenos Aires: Prometeo.

Espina Prieto, M. (2007). “Complejidad, transdisciplina y metodología de la investigación social." Revista Utopía y Praxis Latinoamericana Vol.12, No. 38, pp. 29-43.

Flores Crespo, P. and Mendoza, D. C. (2012). Implementación de políticas educativas: los concursos de oposición para obtener una plaza de trabajo en el marco de la alianza por la calidad de la educación. Universidad Iberoamericana: Mexico.

Galindo Cáceres, J. (1999). “Del objeto construido al objeto percibido." Estudios sobre las culturas contemporáneas. Vol. 5, No 9, pp. 9 -24.

Gianella (2006). "Las disciplinas científicas y sus relaciones." Anales de la educación común, año II, № 3, abril, DGCyE. Buenos Aires, pp. 74 a 83

Glaser, B. and Strauss, A. (1967). The discovery of grounded theory: Strategies for qualitative research. New York: Aldine publishing.

Gómez Campo, V. and Tenti Fanfani, E. (1989) Universidad y profesiones. Crisis y alternativas. Buenos Aires: Miño y Dávila.

Jennings, R.E. (1977). Education and politics: Policy-making in local education authorities. London: B. T. Batsford Limited.

Lasswell, H. (1951). “The Policy Orientation." In: D. Lerner and H. Lasswell, The policy sciences: recent developments in scope and method. Stanford, Stanford University Press

Muller, P. (1990). Les politiques publiques. Paris: PUF.

Muller, P. (2000). "L’analyse cognitive des politiques publiques: vers une sociologie politique de l'action publique." Revue Française de Science Politique, Vol. 50, No. 2, pp. 189-208.

Muller, P. and Surel, Y. (2002). A análise das políticas públicas. Trad. Agemir Bavaresco e Alceu R. Ferraro. Pelotas: EDUCAT.

Raab, Ch. (1994). "Theorising the governance of education." British Journal of Educational Studies, Vol. 42, No.1, pp. 6-22.

Rorty, R. (1989). La filosofía y el espejo de la naturaleza. Madrid, Cátedra. 
Rossetti-Ferreira, M. C., Ramon, F. and Silva, A. P. S. (2002). "Políticas de atendimento à criança pequena nos países em desenvolvimento." Cadernos de Pesquisa, No. 115, pp. 65-100.

Sabatier, P. A. (1988). "An Advocacy coalition framework of Policy Change and the Role of Policy-Oriented Learning Therein." Policy Sciences, Vol.21, 129-168.

Sire, J. (2004). The Universe Next Door: A Basic Worldview Catalogue. Downers Grove, IL: InterVarsity Press.

Sirvent, M. T. (1999). "Problemática actual de la investigación educativa." Revista del Instituto de Investigaciones en Ciencias de la Educación, Vol. 8, No. 14, pp. 64-75.

Tello, C. (2011). “Epistemologías de la política educativa y justicia social en América Latina." Nómadas. Revista Crítica de Ciencias Sociales y Jurídicas, Monográfico América Latina EMUI Euro-Mediterranean University Institute, Spain, pp. 489-500.

Tello, C. (2012a). "Las Epistemologías de la política educativa y la concepción de producción del conocimiento 'basada en la evidencia'." In: N. Fernández Lamarra (comp.) Estudios sobre Políticas Educativas. EDUNTREF: Argentina

Tello, C. (2012b). "Las epistemologías de la política educativa: vigilancia y posicionamento epistemológico del investigar em política educativa." Práxis Educativa, Vol. 7, No. 1, pp. 53- 68, Ponta Grossa.

Tello, C. (2009). "Las epistemologías de la política educativa." Congreso Internacional educación, lenguaje y sociedad: "La educación en los nuevos escenarios socioculturales." La Pampa. Actas..., Argentina.

Tello, C. (2010). "Política Educativa y Fraternidad en América Latina. Notas Epistemológicas." In: O, Barreneche (coord.), Estudios sobre fraternidad. Serie Política y Sociedad. Buenos Aires: Editorial Ciudad Nueva.

Tello, C. (2012c). “Los componentes del EEPE.” I Jornadas Latinoamericanas de Estudios Epistemológicos en Política Educativa. Conferencia Inaugural. Actas... Buenos Aires: UNTREF.

Tello, C. (2013a) “El horizonte del Enfoque de las Epistemologías de la política educativa: la justicia social." In: M. L. Almeida; L., Bonetti and T. Pacievitch $O$ social e as políticas educacionais na contemporaneidade: das desigualdades à violencia no espaço educacional, Campinas: Mercado de Letras.

Tello, C. (2013b). "Notas analíticas sobre el enfoque de las epistemologías de la política educativa." Conjectura: filosofia e educação. Universidades Caxias do Sul. (in press)

Tello, C. (2013c). "Las epistemologías de la política educativa. Notas históricas y epistemológicas sobre el campo." In Tello, C. (org) "Las epistemologías de la política educativa. Enfoques y Perspectivas para el análisis de Políticas educativas." Mercado de Letras. Campinas. SP.

Tello, C. and Mainardes, J. (2012). "La posición epistemológica de los investigadores en Política Educativa: debates teóricos en torno a las perspectivas neo-marxista, pluralista y pos-estructuralista." Education Policy Analysis Archives/Archivos Analíticos de Políticas, Vol. 20, No. 9, Accessed: 10/09/2012. Available online at: http://epaa.asu.edu/ojs/article/view/988

Tenti Fanfani, E. (2007) La escuela y la cuestión social. Buenos Aires, Siglo XXI.

Vitar, A. (2006). Políticas de educación. Razones de una pasión. Buenos Aires: Miño y Dávila.

Wallerstein, I. (1999). Impensar las ciencias sociales, Mexico: Siglo XXI.

Weber, M. (1991 [1918]) El Político y el científico. Madrid: Alianza editorial.

Whitty, G., and Edwards, T. (1994). "Researching Thatcherite education policy." In: G. Walford (ed.) Researching the powerful in education: Social Research today. London: UCL Press Limited, pp. 14-31 